\title{
Pengaruh Kondisi Fisik Rumah dengan Kejadian Penderita Tuberkulosis (TB) Paru.
}

\author{
Asrijun \\ Sekolah Tinggi Ilmu Kesehatan Tamalatea Makassar \\ Email: asrijun@stiktamalateamks.ac.id
}

\begin{abstract}
Pulmonary TB patients in Indonesia are ranked fourth in the world after India, China, South Africa with a prevalence of 285 TB per 100,000 population or as many as 302,861 cases in 2010(Lienhardt dkk. 2012). This research is analytic observation, with case control design. Case control studies were conducted by identifying case groups and control groups. This study aims to determine the risk of physical condition of the house with the incidence of pulmonary TB in the working area of Pattingalloang Health Center, Makassar City. After conducting research, it can be concluded that; (1) There is the influence of the stage house fikik condition with the incidence of pulmonary TB with the risk of transmission 10 times from a healthy stage house. (2) There is an influence of fiksik conditions in semi-permanent homes with the incidence of pulmonary TB but not a significant risk factor. (3) There is an influence of the condition of permanent home fiksik conditions with the incidence of pulmonary TB with risk factors for transmission 6 times from a healthy permanent home.
\end{abstract}

Keywords: Patients, Tuberculosis, Risk Factors, Transmission.

\section{PENDAHULUAN}

Tuberkulosis ( TB ) Paru adalah suatu penyakit menular yang menjadi perhatian dunia. World Health Organisation( $W H O$ ) memperkirakan sepertiga penduduk dunia terinfeksi oleh Mycobacterium tuberculosis dan lima sampai sepuluh persen dari orang - orang yang terinfeksi ini akan menjadi sakit atau menularkan kepada orang lain selama hidupnya. Data WHO tahun 2010 dalam Global Tuberculosis Control menyatakan bahwa terdapat 9,4 juta insiden TB dengan 1,1 juta penderita meninggal dunia. Jumlah insiden TB tertinggi terdapat di Asia Tenggara sebanyak $35 \%$ dari insiden total TB di dunia dengan prevalensi 280 per 100.000 penduduk (Sianturi 2014).

Di Indonesia TB Paru merupakan salah satu masalah kesehatan utama masyarakat. Jumlah pasien TB Paru di Indonesia merupakan peringkat ke tiga dunia setelah India, Cina, Afrika Selatan dengan prevalensi TB 285 per 100.000 penduduk atau sebanyak 302.861 kasus per tahun (Pameswari, dkk 2016).

Lingkungan rumah yang dapat mempengaruhi tingginya kejadian tuberkulosis paru adalah lingkungan rumah yang kurang sehat misalnya kurang adanya fasilitas ventilasi yang baik, pencahayaan yang buruk di dalam ruangan, kepadatan hunian dalam rumah dan bahan bangunan didalam rumah (Nurjana 2015). 
UNM Environmental Journals, Vol. 2 No. 1 Desember 2018 hal. 6-11

Berdasarkan (Profil Kesehatan Kota Makassar (2017) didapatkan data di Dinas Kesehatan Kota makassar ditemukan jumlah kasus baru BTA+ sebanyak 4915 kasus, naik bila dibandingkan kasus baru BTA+ yang ditemukan tahun 2016 yang sebesar 3932 kasus dan tahun 2015 sebesar 3549 kasus. Puskesmas Pattingalloang merupakan salah satu Puskesmas di Kota Makassar dengan jumlah penduduk sebanyak 19.810 jiwa. Laki-laki sebanyak 7.924 jiwa dan perempuan sebanyak 11.886 jiwa. Puskesmas Pattingalloang mempunyai jumlah penderita TB Paru cukup banyak dari 46 Puskesmas, dengan jumlah penderita yang diobati pada tahun 2015 sebanyak 31 kasus, pada tahun 2016 sebanyak 62 kasus, pada tahun 2017 meningkat sebanyak 74 kasus, dan sampai bulan mei 2018 jumlah penderita sebanyak 50 kasus yang tersebar di 4 kelurahan wilayah kerja. Puskesmas Pattingalloang dengan kondisi geografisnya sebagian di pesisir pantai dan daerah kumuh padat . Berdasarkan usia penderita TB Paru terbanyak pada usia produktif yaitu antara umur 21-45 tahun, sedangkan dilihat dari jenis kelamin yang dominan adalah laki-laki sebanyak 29 kasus (59\%). Kondisi geografis yang demikian memungkinkan tingginya kejadian penyakit tuberkulosis paru.

Berdasarkan uraian di atas maka penulis merumuskan masalah penelitian yaitu bagaimana "Pengaruh Kondisi Fisik Rumah dengan Kejadian Penderita Tuberkulosis (TB) Paru Di Wilayah Kerja Puskesmas Pattingalloang berdasarkan kondisi fisik rumah panggung, semi permanen dan permanen

\section{METODE}

Penelitian ini adalah observasi analitik, dengan desain case kontrol. Studi kasus kontrol dilakukan dengan mengindentifikasi kelompok kasus dan kelompok kontrol, kemudian secara retrospektif diteliti faktor-faktor resiko yang mungkin dapat menerangkan apakah kasus dan kontrol dapat terkena paparan atau tidak. Penelitian ini bertujuan untuk mengetahui besar risiko kondisi fisik rumah dengan kejadian TB Paru di wilayah kerja Puskesmas Pattingalloang Kota Makassar.

\section{HASIL PEMBAHASAN}

\section{Hubungan Kondisi Fisik Rumah Panggung dengan kejadian TB Paru}

Tabel 3.1 Distribusi Hubungan Kondisi Fisik Rumah Panggung dengan Kejadian TB Paru di Wilayah Kerja Puskesmas Pattingalloang Kota Makassar Tahun 2018

\begin{tabular}{|c|c|c|c|c|c|c|c|c|}
\hline \multirow{3}{*}{$\begin{array}{c}\text { Kondisi Fisik } \\
\text { Rumah Panggung }\end{array}$} & \multicolumn{4}{|c|}{ Kejadian TB Paru } & \multirow{2}{*}{\multicolumn{2}{|c|}{ Jumlah }} & \multirow{3}{*}{$p$} & \multirow{3}{*}{$O R(C I)$} \\
\hline & \multicolumn{2}{|c|}{ Kasus } & \multicolumn{2}{|c|}{ Kontrol } & & & & \\
\hline & $\mathrm{n}$ & $\%$ & $\mathrm{n}$ & $\%$ & $\mathrm{n}$ & $\%$ & & \\
\hline Kurang Sehat & 8 & 67 & 2 & 17 & 10 & 42 & \multirow{3}{*}{0,013} & \multirow{3}{*}{$\begin{array}{c}10,00 \\
(1,44-69)\end{array}$} \\
\hline Sehat & 4 & 33 & 10 & 83 & 14 & 58 & & \\
\hline Total & 12 & 100 & 12 & 100 & 24 & 100 & & \\
\hline
\end{tabular}

Hasil penelitian dapat dilihat bahwa total dari Kondisi fisik rumah panggung kasus yang terbanyak adalah kurang sehat yaitu $67 \%$ sedangkan yang sehat hanya $33 \%$. Sedangkan pada kontrol yang memiliki rumah yang sehat sebanyak $83 \%$ responden dan yang kurang sehat sebanyak $17 \%$ responden. Dari hasil uji statistik didapatkan nilai Odds ratio 10,000 CI: 95\% (1,44- 69,62) yang artinya responden yang memiliki rumah dengan kondisi yang kurang sehat akan beresiko menderita TB Paru sebesar 10 kali dibandingkan dengan responden yang memilki rumah dengan hunian yang sehat (Syafri 2015). Hasil uji statistic Pearson Chi-Square Test diperoleh nilai $p<0,05(p=0,013)$, maka terdapat hubungan yang bermakna antara kondisi fisik rumah panggung dengan kejadian TB Paru di Wilayah kerja Puskesmas Pattingalloang Kota Makassar. 


\section{Hubungan Kondisi Fisik Rumah Semi Permanen dengan kejadian TB Paru}

Tabel 3.2 Distribusi Hubungan Kondisi Fisik Rumah Semi Permanen dengan Kejadian TB Paru di Wilayah Kerja Puskesmas Pattingalloang Kota Makassar Tahun 2018

\begin{tabular}{|c|c|c|c|c|c|c|c|c|}
\hline \multirow{3}{*}{$\begin{array}{c}\text { Kondisi Fisik } \\
\text { Rumah Semi } \\
\text { Permanen } \\
\end{array}$} & \multicolumn{4}{|c|}{ Kejadian TB Paru } & \multirow{2}{*}{\multicolumn{2}{|c|}{ Jumlah }} & \multirow{3}{*}{$p$} & \multirow{3}{*}{$O R(C I)$} \\
\hline & \multicolumn{2}{|c|}{ Kasus } & \multicolumn{2}{|c|}{ Kontrol } & & & & \\
\hline & $\mathrm{n}$ & $\%$ & $\mathrm{n}$ & $\%$ & $\mathrm{n}$ & $\%$ & & \\
\hline Kurang Sehat & 12 & 100 & 5 & 42 & 17 & 71 & & \\
\hline Sehat & 0 & 0 & 7 & 58 & 7 & 29 & 0,005 & - \\
\hline Total & 12 & 100 & 12 & 100 & 24 & 100 & & \\
\hline
\end{tabular}

Hasil penelitian dapat dilihat bahwa total dari Kondisi fisik rumah semi permanen pada kelompook kasus yang terbanyak adalah kurang sehat yaitu $100 \%$ sedangkan yang sehat $0 \%$. Sedangkan pada kelompok kontrol yang memiliki rumah yang sehat sebanyak 58\% responden dan yang kurang sehat sebanyak $42 \%$ responden. Dari hasil uji statistik tidak diperoleh nilai Odds ratio sehingga tidak diperoleh informasi tentang faktor risiko. Hasil uji statistic Fisher Exact Test diperoleh nilai $p<0,05(p=0,005)$, maka terdapat hubungan yang bermakna antara kondisi fisik rumah semi permanen dengan kejadian TB Paru di Wilayah kerja Puskesmas Pattingalloang Kota Makassar.

\section{Hubungan Kondisi Fisik Rumah Permanen dengan kejadian TB Paru}

Grafik 3.3 Distribusi Hubungan Kondisi Fisik Rumah Permanen dengan Kejadian TB Paru di Wilayah Kerja Puskesmas Pattingalloang Kota Makassar Tahun 2018

\begin{tabular}{ccccccccc}
\hline \multirow{2}{*}{$\begin{array}{c}\text { Kondisi Fisik } \\
\text { Rumah Permanen }\end{array}$} & \multicolumn{3}{c}{ Kejadian TB Paru } & \multirow{2}{*}{ Jumlah } & \multirow{2}{*}{ Kontrol } & & \multirow{2}{*}{ OR $(C I)$} \\
\cline { 2 - 7 } & $\mathrm{n}$ & $\%$ & $\mathrm{n}$ & $\%$ & $\mathrm{n}$ & $\%$ & & \\
\hline Kurang Sehat & 9 & 75 & 4 & 33 & 13 & 54 & & 6,000 \\
Sehat & 3 & 25 & 8 & 67 & 11 & 46 & \multirow{2}{*}{0,041} & $(1,018-$ \\
\hline Total & 12 & 100 & 12 & 100 & 24 & 100 & & $35,373)$ \\
\hline
\end{tabular}

Hasil penelitian dapat dilihat bahwa total dari Kondisi fisik rumah permanen pada kelompok kasus yang terbanyak adalah kurang sehat yaitu $75 \%$ sedangkan yang sehat $25 \%$. Sedangkan pada kelompok kontrol yang memiliki rumah yang sehat sebanyak $67 \%$ responden dan yang kurang sehat sebanyak 33\% responden. Dari hasil uji statistik didapatkan nilai Odds Ratio: 6,000 CI: 95\% (1,01835,373 ) yang artinya responden yang memiliki rumah dengan kondisi yang kurang sehat akan beresiko menderita TB Paru sebesar 6 kali dibandingkan dengan responden yang memilki rumah dengan hunian yang sehat. Hasil uji statistic Pearson Chi-Square Test diperoleh nilai $p<0,05(p=0,041)$, maka sependapat dengan penelitian Nurjana (2015) bahwa terdapat hubungan yang bermakna antara kondisi fisik rumah panggung dengan kejadian TB Paru di Wilayah kerja Puskesmas Pattingalloang Kota Makassar. 
UNM Environmental Journals, Vol. 2 No. 1 Desember 2018 hal. 6-11

\section{Pembahasan}

\section{Kondisi Fisik Rumah Panggung}

Hasil penelitian tentang Kondisi fisik rumah panggung terdapat total yang tidak memenuhi syarat adalah $42 \%$ dan yang memenuhi syarat yaitu 58\%. Dalam Kondisi fisik rumah panggung (tidak memenuhi syarat), paling banyak terdapat pada kasus yaitu 67\% sedangkan pada kontrol hanya 33\%. Hasil uji statistic diperoleh nilai $\mathrm{p}<0,05(\mathrm{p}=0,013)$, maka terdapat hubungan yang bermakna antara Kondisi rumah panggung dengan kejadian TB Paru di wilayah kerja Puskesmas Pattingalloang kota Makassar, dimana kondisi fisik rumah panggung merupakan faktor resiko dengan $\mathrm{OR}=10,000$, ini berarti kondisi fisik rumah panggung yang kurang sehat memiliki resiko penularan 10 kali dari rumah panggung yang sehat.

Menurut Ayomi, dkk (2012) salah satu syarat bangunan rumah sehat adalah harus cukup untuk penghuni di dalamnya, artinya luas lantai bangunan rumah tersebut harus disesuaikan dengan jumlah penghuninya agar tidak menyebabkan overload. Hal ini tidak sehat, sebab disamping menyebabkan kurangnya konsumsi oksigen juga bila salah satu anggota keluarga terkena penyakit infeksi, akan mudah menular kepada anggota keluarga yang lain.

Disamping itu yang paling mendasar pada rumah panggung adalah, posisi atau letak dari ruangan keluarga, dimana posisi ruangan keluarga berada di bagian bawah rumah yang cenderung ruangan tertutup, sehingga menjadi faktor risiko penyebaran penyakit TB karena ventilasi, pencahayaan tidak sampai pada ruang bawah yang menjadi ruang berkumpulnya keluarga. Dari hasil penelitian (Nurjana 2015), tentang faktor-faktor yang berhubungan dengan kejadian TB Paru pada usia dewasa, dari hasil analisa statistik menunjukkan adanya hubungan yang bermakna dengan didapatkan hasil odds ratio sebesar 5,983 dengan $95 \%$ Confidence Interval 1,606 - 22,293, dengan nilai $\mathrm{p}=$ 0,0047 .

Penelitian yang telah dilakukan oleh Toni Lumban Tobing (2009), tentang Pengaruh Perilaku Penderita TB Paru dan Kondisi Sanitasi terhadap Pencegahan Potensi Penularan TB Paru Pada Keluarga di Kabupaten Tapanuli Utara, Dari hasil penelitian tersebut ditemukan kondisi kepadatan hunian memiliki hubungan yang signifikan terhadap penyakit TB. Dapat dilihat dari Ods Ratio sebesar 3,3 artinya yaitu kepadatan hunian yang kurang mempunyai resiko tertular TB Paru sebesar 3,3 kali lebih banyak dari yang kondisi kepadatan huniannya baik.

Hal ini memiliki kesamaan dengan hasil penelitian yaitu kondisi fisik rumah yang cenderung tidak memenuhi syarat sangat mempengaruhi penularan penyakit TB Paru, karena kuman TB Paru dapat ditularkan lewat media udara sehingga jika rumah padat penghuni kuman ini mudah sekali menular.

\section{Kondisi Fisik Rumah Semi Permanen}

Hasil penelitian dapat dilihat bahwa total dari kondisi fisik rumah semi permanen kasus dan control yang terbanyak adalah kondisi rumah semi permanen yang kurang sehat yaitu $71 \%$ sedangkan kondisi fisik rumah sehat $29 \%$. Pada kondisi fisik rumah semi permanen yang kurang sehat semuanya menderita $100 \%$ responden. Hasil uji statistik diperoleh nilai $p<0,05(\mathrm{p}=0,005)$, maka terdapat hubungan yang bermakna antara kondisi fisik rumah semi permanen dengan kejadian TB Paru di wilayah keja Puskesmas Pattingalloang Kota Makassar, dimana kondisi fisik rumah semi permanen bukan merupakan faktor resiko dengan nilai $\mathrm{OR}=0,000$.

Hasil penelitian yang dilakukan oleh Musadad (2001), yang melakukan penelitian hubungan faktor lingkungan rumah dengan kejadian penularan TB Paru di rumah tangga, dari penelitian tersebut didapatkan bahwa kondisi pencahayaan yang kurang mempunyai resiko 3,7 kali terkena TB Paru bila dibandingkan dengan rumah yang dimasuki sinar matahari.

Hal ini tidak sesuai dengan hasil penelitian yang dilakukan oleh Toni Lumban Tobing (2009), tentang Pengaruh Prilaku Penderita TB Paru dan Kondisi Sanitasi terhadap Pencegahan Potensi Penularan TB Paru, hasil penelitiannya didapatkan $\mathrm{p}=0,000$ berarti ada hubungan antara kondisi pencahayaan dengan penularan TB Paru. Hasil statistik odds Ratio 5,9 dengan CI 95\% (1,928-18,201) jadi kondisi pencahayaan yang kurang mempunyai resiko penularan sebanyak 5,9 kali dari kondisi pencahayan yang baik. 
Menurut penelitian ini difokuskan pada faktor pencahayaan yang merupakan faktor resiko yang cukup signifikan, karena cahaya matahari merupakan salah satu faktor yang dapat membunuh kuman TB Paru, namun hasil dilapangan didapatkan bahwa pencahayaan tidak menembus sampai dalam ruangan, hal ini disebabkan karena kondisi bangunan yang berada di pemukiman padat yang saling berdempetan, sehingga menghalangi pencahayaan masuk ke dalam rumah. Disamping itu dari hasil penelitian di lapangan dijumpai rumah kurang sehat (pencahayaan kurang) di jumpai pada kasus (responden yang terkena TB Paru) lebih banyak di bandingkan dengan kelompok kontrol.

\section{Kondisi Fisik Rumah Permanen}

Hasil penelitian tentang Kondisi fisik rumah permanen responden didapat total kurang sehat adalah 54\% dan yang sehat sebesar $46 \%$, kondisi rumah permanen yang kurang sehat paling banyak terdapat pada kasus yaitu 75\% sedangkan pada kontrol hanya 25\%. Hasil uji statistik diperoleh nilai $p$ $<0,05$ ( $\mathrm{p}=0,041$ ), maka terdapat hubungan yang bermakna antara kondisi rumah permanen dengan kejadian TB Paru di wilayah kerja Puskesmas Pattingalloang Kota Makassar, dimana kondisi kondisi fisik rumah permanen merupakan faktor resiko dengan $\mathrm{OR}=6,000$, ini berarti kondisi fisik rumah permanen yang kurang sehat memiliki resiko penularan 6 kali dari rumah permanen yang sehat.

Hal ini sesuai dengan hasil penelitian yang dilakukan oleh Tobing (2009), tentang Pengaruh Perilaku Penderita TB Paru dan Kondisi Sanitasi terhadap Pencegahan Potensi Penularan TB Paru, dari penelitian tersebut di dapatkan bahwa kondisi ventilasi rumah yang tidak memenuhi syarat matahari mempunyai resiko 2,4 kali terkena TB Paru bila dibandingkan dengan rumah yang kondisi ventilasi yang baik.

Hal yang sama juga terdapat pada penelitian yang dilakukan oleh Suarni (2009), tentang faktor resiko yang berhubungan dengan kejadian penderita TB Paru di Kecamatan Pancoran Mas Depok tahun 2009, di dapatkan hasil penelitian bahwa kondisi ventilasi rumah merupakan faktor resiko dengan $\mathrm{OR}=14,182$, ini berarti kondisi ventilasi yang kurang memiliki resiko penularan 14,182 kali dari ventilasi yang baik.

Ini menunjukan bahwa ventilasi memiliki peranan besar terhadap penularan penyakit TB Paru. Hasil penelitian di lapangan didapatkan bahwa, sebagian besar responden yang memiliki rumah permanen kondisi ventilasi dan sumber pencahayaan dalam keadaan tertutup/kurang sehat. ini terlihat dari hasil pengamatan bahwa responden yang memiliki rumah permanen umumnya menggunakan mesin pendingin ruangan (AC) sehingga rumah dibiarkan tertutup dari sirkulasi udara dan pencahayaan.

\section{KESIMPULAN DAN SARAN}

Hasil observasi, wawancara, serta uji statistik dalam penelitian di wilayah kerja Puskesmas Pattingalloang Kota Makassar, maka dapat ditarik kesimpulan sebagai berikut:

1. Ada pengaruh faktor kondisi fiksik rumah panggung dengan kejadian TB Paru dengan risiko penularan 10 kali dari rumah panggung yang sehat.

2. Ada pengaruh faktor kondisi fiksik rumah semi permanen dengan kejadian TB Paru namun tidak menjadi faktor risiko yang bermakna.

3. Ada pengaruh faktor kondisi fiksik rumah permanen dengan kejadian TB Paru dengan faktor risiko penularan 6 kali dari rumah permanen yang sehat. 
UNM Environmental Journals, Vol. 2 No. 1 Desember 2018 hal. 6-11

\section{DAFTAR RUJUKAN}

[1] Ayomi, Andreas Christian, Onny Setiani, dan Tri Joko. 2012. "Faktor Risiko Lingkungan Fisik Rumah dan Karakteristik Wilayah Sebagai Determinan Kejadian Penyakit Tuberkulosis Paru di Wilayah Kerja Puskesmas Sentani Kabupaten Jayapura Provinsi Papua.” Jurnal Kesehatan Lingkungan Indonesia 11(1): 1-8.

[2] Lienhardt, Christian dkk. 2012. "Global tuberculosis control: lessons learnt and future prospects." Nature Reviews Microbiology 10(6): 407.

[3] Nurjana, Made Agus. 2015. "Faktor risiko terjadinya Tuberculosis paru usia produktif (15-49 tahun) di Indonesia." Media Penelitian dan Pengembangan Kesehatan 25(3).

[4] Pameswari, Puspa, Auzal Halim, dan Lisa Yustika. 2016. "Tingkat Kepatuhan Penggunaan Obat pada Pasien Tuberkulosis di Rumah Sakit Mayjen H. A Thalib Kabupaten Kerinci.” Jurnal Sains Farmasi \& Klinis 2(2): 116-121.

[5] "Profil Kesehatan Kota Makassar (2017) (Mei 2, 2019).

[6] Sianturi, Ruslantri. 2014. "Analisis faktor yang berhubungan dengan kekambuhan TB paru (studi kasus di BKPM Semarang tahun 2013)." Unnes Journal of Public Health 3(1).

[7] Syafri, Amalia Kartika. 2015. "Hubungan kondisi fisik rumah dengan kejadian Tuberkulosis paru di Wilayah Kerja Puskesmas Ngemplak Boyolali.” PhD Thesis. Universitas Muhammadiyah Surakarta. 